\title{
Conflict of Interest Disclosure in a Top-Tier Portuguese Medical Journal
}

\author{
Divulgação de Conflitos de Interesse numa Revista \\ Médica Portuguesa de Referência
}

\author{
Nuno Moreira FONSECA $\triangle 1$ \\ Acta Med Port 2017 Sep;30(9):652-655 - https://doi.org/10.20344/amp.8458
}

\section{ABSTRACT}

Introduction: Scientific medical publications are considered to be a source of unbiased and independent information. Authors are required to disclose relationships with the pharmaceutical industry for transparency purposes. The aim of this work was to assess conflict of interest disclosure in a Portuguese top-tier medical journal by comparing authors' self-reported conflicts of interest with payments listed in the official database of Portuguese Ministry of Health.

Material and Methods: All articles published in the Portuguese Journal of Cardiology from December 2015 to May 2016 were reviewed. Articles based on clinical images, with authors affiliated to foreign institutions, editorials, letters to the editor, or submitted before January $1^{\text {st }} 2015$ were excluded. Authors were categorized on concordance between self-reported disclosures and payments listed in the database. Authors who authored multiple articles were counted as new authors, since each paper offered a new opportunity for financial disclosure.

Results: Of the 155 authors surveyed, 82 (53\%) were in perfect concordance with the sunshine database, while 73 authors (47\%) had one or more undisclosed payments. Undisclosed payments totaled over $€ 210000$. Four (17\%) articles mentioned a conflict of interest, 24 articles $(96 \%)$ had at least one author with undisclosed payments.

Discussion: None of the payments listed in the database was acknowledged in self-reported conflicts of interest. This might indicate that authors do not consider their financial relationships with the industry to be relevant.

Conclusion: The lack of concordance between self-reported conflicts of interest and payments found in the database raises concerns about incomplete disclosure.

Keywords: Conflict of Interest; Disclosure; Editorial Policies; Periodicals as Topic; Portugal

\section{RESUMO}

Introdução: As publicações médicas são consideradas uma fonte de informação fidedigna e independente. Por motivos de transparência é exigido aos autores que divulguem as suas relações com a indústria farmacêutica. Os objectivos do presente estudo consistiram em avaliar a divulgação de conflitos de interesse numa publicação médica de referência, comparando os conflitos de interesse declarados pelos autores com os pagamentos listados na plataforma de transparência do Ministério da Saúde.

Material e Métodos: Foram analisados todos os artigos publicados na Revista Portuguesa de Cardiologia entre dezembro de 2015 e maio de 2016. Critérios de exclusão: artigos baseados em imagens clínicas, artigos com autores afiliados a instituições estrangeiras, editoriais, cartas ao editor e trabalhos com data de submissão anterior a 1 de janeiro de 2015. Os autores foram classificados segundo a concordância entre os conflitos de interesse declarados e os pagamentos listados na plataforma de transparência. Os autores que publicaram mais do que artigo incluído na análise foram classificados como novo autor, uma vez que cada publicação permite uma nova oportunidade de divulgação de conflitos de interesse.

Resultados: Dos 155 autores analisados, 82 (53\%) estavam em plena concordância com os dados da plataforma, enquanto 73 autores $(47 \%)$ apresentavam pelo menos um pagamento não divulgado. $O$ total dos pagamentos não divulgados ascendia a $€ 210$ 000. Quatro (17\%) artigos referiam conflitos de interesse, 24 artigos (96\%) continham pelo menos um autor com pagamentos não divulgados.

Discussão: Nenhum dos pagamentos listado na plataforma foi mencionado nos conflitos de interesse dos autores. Tal facto poderá indicar que os autores não consideram relevantes as suas relações financeiras com a indústria.

Conclusão: A discordância encontrada entre conflitos de interesse declarados e os pagamentos suscita preocupação sobre divulgação insuficiente dos conflitos de interesse.

Palavras-chave: Conflito de Interesse; Políticas Editoriais; Portugal; Publicações; Revelação da Verdade

\section{INTRODUCTION}

A conflict of interest can involve personal, professional, political or religious views, but, it most often refers to financial relationships. ${ }^{1}$ For the purpose of this paper, only financial relationships will be considered. Reporting of conflicts of interest in scientific literature has been the object of debate for many years. To this day, there is no consensus about the definition for conflict of interest (COI) or what should be reported. Nevertheless, important steps have been taken to find a certain degree of uniformization of disclosure.
Since 2009, the International Committee of Medical Journal Editors (ICMJE), a working group of general medical journal editors (including the British Medical Journal, and New England Journal of Medicine) has implemented a uniform format for disclosure of competing interests in journal articles. ${ }^{2}$ The ICMJE form requires authors to disclose their associations with commercial entities that provided support for the work submitted; associations with commercial entities that could be viewed as having an interest in the

1. Serviço de Nefrologia. Hospital Curry Cabral. Centro Hospitalar de Lisboa Central. Lisboa. Portugal.

$\bowtie$ Autor correspondente: Nuno Moreira Fonseca. nuno.mf@nyu.edu

Recebido: 10 de novembro de 2016 - Aceite: 03 de maio de 2017 | Copyright @ Ordem dos Médicos 2017 
general area of the submitted manuscript; information about relevant financial relationships outside the submitted work; financial relationships involving children (under 18 years of age) or spouse/partner ; as well as nonfinancial associations that may be relevant to the submitted manuscript. ${ }^{2}$ The ICMJE disclosure form has since been updated and no longer requires information pertaining to children or spouse/ partner to be included. ${ }^{3}$

While efforts were being made on the standardization of disclosure forms by journal editors, several governments developed national "sunshine" policies aimed at improving transparency of financial relationships between the pharmaceutical industry and healthcare professionals..$^{4,5}$ In 2013, the Portuguese ministry of health implemented a "sunshine" policy and created an online public access database (Plataforma de Comunicações Transparência e Publicidade, https://placotrans.infarmed. pt/Publico/ListagemPublica.aspx), hereafter mentioned as transparency database. This transparency database lists in detail all payments made by the pharmaceutical industry regarding any grant, sponsorship, endowment or any good with pecuniary value, to any person or legal entity, including patient associations or medical societies, provided that the payment is over $€ 60$.

Disclosing $\mathrm{COI}$ is useful because it helps the reader understand what are the relationships between the authors and various commercial entities that have special interests in the reported information. ${ }^{2}$ The aim of this paper was to assess disclosure of $\mathrm{COI}$ made in a Portuguese top-tier medical journal that adheres to ICMJE's ethical responsibilities, by comparing self-reported $\mathrm{COI}$ with payments listed in the transparency database.

\section{MATERIAL AND METHODS}

This study reviews all articles published in the Portuguese Journal of Cardiology (ISSN: 0870-2551, Impact Factor 2015: 0.873; Medline Index) over six months (from December 2015 to May 2016). Authors' selfreported $\mathrm{COI}$ were compared to payments reported in the transparency database for the years of 2013 and 2014. Thus one exclusion criteria was a submission date before January $1^{\text {st }} 2015$, to ensure that the reviewed payments had already been made by the time of the articles' submission. In addition to this, articles with authors affiliated to foreign institutions were excluded, considering the national scope of the transparency database. Lastly, articles based on clinical images, editorials and letters to the editor, were excluded, for lesser significance.

Information collected from the transparency database included amount, source, and nature of payments. Authors who authored multiple articles were counted as new authors, since each paper offered a new opportunity for financial disclosure. For each author, payments in the database were compared to self-reported $\mathrm{COI}$ and were categorized as disclosed or undisclosed. Authors were categorized based on concordance between self-reported financial disclosures and payments listed in the database.
Results were analyzed using descriptive statistics.

\section{RESULTS}

During the 6-month study period there were 92 articles and editorials published. 67 papers met the exclusion criteria: articles with authors affiliated to foreign institutions (25), submission date prior to January $1^{\text {st }} 2015$ (4), clinical image based articles (17), letters to the editor (4), and editorials or editors' commentaries (17). The 25 articles that met the inclusion criteria were submitted by 155 authors. Of the 25 articles surveyed, 21 (84\%) had no self-reported COI or acknowledgment of funding, while $4(16 \%)$ articles had some form of disclosure: I) the authors reported no COI but disclosed funding in a separate vignette (one article - 4\%); II) the authors reported funding under the $\mathrm{COI}$ vignette (one article - 4\%); III) the authors acknowledged the employment relationship of one author with a pharmaceutical company under the COI vignette (one article - 4\%); IV) the authors reported no $\mathrm{COI}$ but disclosed funding in a separate vignette from a pharmaceutical company, and acknowledged the employment relationship of one of the authors with a second pharmaceutical company also outside the COI vignette (one article - 4\%).

Other than disclosing funding specifically destined for the published works in question (3 articles - 12\%), no other payments were reported. A review of the transparency database retrieved 267 payments to $73(47 \%)$ authors, while 82 authors (53\%) had no payments listed, while 24 articles $(96 \%)$ had at least one author with undisclosed payments. None of the payments listed in the transparency database was acknowledged in self-reported $\mathrm{COI}$, making the rate of disclosure for authors with payments $0 \%$. For this reason, concordance among self-reported $\mathrm{COI}$ and payments in the transparency database was similar to the percentage of authors without any payments listed (53\%).

Payments listed in the transparency database totaled $€$ 219 909.36. The average number of payments per author was 3.7. The most highly paid author received $€ 10931.13$ Of the 73 authors with payments listed, $2(3 \%)$ had received over $€ 10000,11(15 \%) € 10000-€ 5000,36(49 \%) € 5000$ - $€ 1000$, and 24 (33\%) less than $€ 1000$. Most payments listed related to participation in scientific meetings (59.9\%), followed by payments related to pharmaceutical promotional events (15.7\%), honoraria for lectures/moderation/ consulting/participation in advisory boards or clinical trials $(11.2 \%)$, continuing medical education events $(7.5 \%)$, and meals $(4.9 \%)$.

\section{DISCUSSION}

This study of a major medical Portuguese publication showed a lack of concordance between authors' acknowledged $\mathrm{COI}$ and their financial payments in the transparency database. In spite of the degree of discordance found in this study, failing to report financial ties does not necessarily imply any undue conflict of interest.

The ICMJE requires that payments related to board membership, consultancy, employment, expert testimony, 
gifts, grants, pending grants, payment for manuscript preparation, patents (planned, pending or issued), royalties, payment for development of educational presentations including service on speakers' bureaus, stock, stock options, travel or accommodation expenses covered or reimbursed, or others, made by any entity that could be considered broadly relevant to the published work to be reported. ${ }^{3,6}$ These results show unequivocally that when self-reporting COI authors greatly under report payments from the pharmaceutical industry. It is conceivable that most authors fail to report industry payments for considering that their financial relationships with industry are not relevant or are outside of the topic of the submitted work. However, ICMJE requirements are vastly comprehensive and additionally include the disclosure of "financial activities outside the submitted work". It might be argued that systematically disclosing all financial ties is not an effective mean to produce intelligible data to assess an undue $\mathrm{COI}^{7} \mathrm{~A}$ reply to this assertion would be that a culture of no disclosure, which, according to these results seems to be the prevailing one, will inevitably be worse. After reviewing payments listed in the database, it was noticed that in one of the studies that acknowledged pharma funding, one author failed to disclose previous consultancy honoraria from that same company. Whether one agrees with comprehensiveness of the ICMJE requirements or not, in this particular instance, it seems clear that an author who receives multiple payments from a pharmaceutical company has something to disclose when authoring a paper funded by that same company. Moreover, this particular paper compares two drugs, and concludes that the drug marketed by the company that funds study achieves better clinical results at a lower cost. The point here is not to judge the reliability of the data of this study nor to raise any suspicion on the integrity of this particular author. Instead, the point is, when over $€ 200000$ of industry payments go unreported, it is easy to understand how even payments that fall under the most consensual conceptions of $\mathrm{COI}$ can be omitted. While this specific situation of underreporting might only require a simple clarification from the author, enhancing author's disclosures and editorial verification might facilitate the prevention of similar situations.

Readers trust scientific publications to be a source of unbiased and independent information, and perceive them as beneficial for the advancement of care, which in turn results in a need for editorial accountability. ${ }^{8}$ In order to assure the quality and integrity of the material published, editorial policy must ensure that journal standards for publication are met. Until this point, self-reporting has been the policy that has governed the ethics of publication. As transparency policies evolve with time, would it not be logical and appropriate for editorial policy to adapt? I suggest that the advent of databases that list in detail financial relationships between industry and professionals has the potential to help editors fulfill their mission.

There are limitations to this study, which may be subjected to a selection bias as it focuses on a single specialized journal as opposed to a more general medical journal, surveying only a relatively short period of time (6 months). While underreporting is an issue of its own, the importance of the interactions between professionals and the industry is not to be underestimated. Many innovative and groundbreaking treatments were only made possible through joint ventures that have benefited the entire world population. Such is the case of the development of streptomycin and the treatment of tuberculosis. ${ }^{2} \mathrm{COI}$ are impossible to eradicate and preserving industryprofessionals collaborations will require the best possible management of these conflicts. ${ }^{9}$ A step forwards in this complex process could stem from a change in terminology. Along this line of thought the British Medical Journal has replaced the term 'conflicts of interest' for 'competing interests'. However, both denominations presuppose a pejorative relation of antagonism, which may lead to the unstated presumption that prevails to this day of 'guilty until proven innocent'. ${ }^{10}$ For this reason, using the term 'bonds of interest' instead might be a more suitable option that will perhaps not deter authors from disclosing payments.

\section{CONCLUSION}

This study suggests that when submitting medical publications authors greatly underreport financial relationships as conflicts of interest. Some authors also fail to disclose funding as conflict of interest. While the best response to conflicts of interest seems to be disclosure, public access databases that contain lists of payments to healthcare professionals can be a tool for editorial teams to enhance accuracy of authors' self-reported conflicts of interest.

\section{CONFIDENTIALITY OF DATA}

The author declares having followed the protocols in use at their working center regarding patient's data publication.

\section{CONFLICTS OF INTEREST}

The views expressed in this article are those of the author and do not necessarily reflect the position or policy of the Centro Hospitalar de Lisboa Central. The author has received payments made by Sanofi and Astellas (to participate in scientific meetings), AstraZeneca (for continuing medical education activities), and Fulbright Commission (for graduate studies).

\section{FUNDING SOURCES}

No funding was obtained for the development of this work.

\section{REFERENCES}

1. Goozner M, Caplan A, Moreno J, Kramer BS, Babor TF, Husser WC. A common standard for conflict of interest disclosure in addiction journals.
Addiction. 2009;104:1779-84.

2. Drazen JM, Weyden MB, Sahni P, Rosenberg J, Marusic A, Laine C, 
et al. Uniform format for disclosure of competing interests in ICMJE journals. N Eng J Med. 2009;361:1896-7.

3. International Committee of Medical Journal Editors. Conflicts of interest. [accessed 2017 Feb 28]. Available from: http://icmje.org/conflicts-ofinterest/.

4. Santhakumar S, Adashi EY. The Physician Payment Sunshine Act: testing the value of transparency. JAMA. 2015;313:23-4.

5. Campbell DJ, Sharkey BP. Sunshine spreading across the Atlantic and over Europe. Med Writing. 2013;22:248-51.

6. Drazen JM, de Leeuw PW, Laine C, Mulrow C, DeAngelis CD, Frizelle FA, et al. Towards more uniform conflict disclosures. BMJ. 2010;340:c3239.

7. Rosenbaum L. Understanding bias-the case for careful study. N Eng J Med. 2015;372:1959-63.

8. Steinbrook R, Kassirer JP, Angell M. Justifying conflicts of interest in medical journals: a very bad idea. BMJ. 2015;350:h2942.

9. Smith R. Conflicts of interest: how money clouds objectivity. J R Soc Med. 2006;99:292-7.

10. Hirsch LJ. Conflicts of interest, authorship, and disclosures in industryrelated scientific publications: the tort bar and editorial oversight of medical journals. Mayo Clin Proc. 2009;84:811-21. 